\title{
Shaping sustainable development to support human welfare
}

\author{
Hrvoje Mikulčić ${ }^{1} \cdot J^{\text {Jiři Jaromír Klemeš }}{ }^{2} \cdot$ Neven Duić $^{1}$
}

Received: 15 August 2016/ Accepted: 15 August 2016/Published online: 23 August 2016

(C) Springer-Verlag Berlin Heidelberg 2016

\begin{abstract}
Due to increased environmental awareness and social responsibility, social and human welfare have been increasingly viewed through the prism of sustainable development. As sustainable development is a highly multi-disciplinary field of research, a considerable number of studies have been devoted to this issue. The studies show that sustainable development has become an urgent task for the international community, academia, industry experts, policy makers and the general public, due to the rapidly growing social challenges of mankind. This review article provides a short assessment of the current state-of-the art papers related to sustainable development covered in the recent publications mostly originated from previous SDEWES conferences.
\end{abstract}

Keywords Life cycle assessment · Future energy system · Water-energy nexus · Waste management $\cdot \mathrm{CO}_{2}$ emission reduction - Mathematical modelling - Social and economic study

\section{Introduction}

As the concept of sustainable development, universally accepted as a means of protecting the environment for all mankind, demands that future manufacturing technologies shall be cleaner, more socially aware, yet economically

Hrvoje Mikulčić

hrvoje.mikulcic@fsb.hr; neven.duic@fsb.hr

Jiři Jaromír Klemeš

klemes.jiri@itk.ppke.hu

1 Faculty of Mechanical Engineering and Naval Architecture, University of Zagreb, Ivana Lučića 5, 10000 Zagreb, Croatia

2 Faculty of Information Technology and Bionics, Práter utca 50/a, 1083 Budapest, Hungary sound, an interdisciplinary approach that involves an interaction of different systems is needed to tackle this issue. The Clean Technologies and Environmental Policy Journal with its international community interested in new technologies, mathematical and computer-based methods and models for designing, analysing, and measuring cleanliness of products and processes, management of environmental systems such as: ecosystems, watersheds, and manufacturing networks; and finally in the research in scientific, social, behavioural, and economics disciplines that are relevant to complex environmental policy issues in fields such as: products, processes and manufacturing networks; wastewater collection and treatment; air pollution control technologies; hazardous toxic waste management; fate and transport of contaminants in the environment; environmental regulations and compliance; pollution prevention; solid waste management; and conservation and environmental protection, has shown that in order to tackle the sustainability issue, interdisciplinary approach that involves interaction of different systems is needed. This review paper briefly assesses seven groups of papers that address the sustainability issue. These seven groups of papers are named as life cycle assessment; future energy systems; water-energy nexus and water networks; waste management; $\mathrm{CO}_{2}$ emission from industry and due to land use change for biofuel cultivation; mathematical modelling and numerical simulations; social and economic studies. To give the readers of Clean Technologies and Environmental Policy Journal a sense of continuity, a review on some of the previously published papers has been provided in this review.

\section{Life cycle assessment}

Over the years, life cycle assessment (LCA) has emerged as a valuable decision-support tool for both policy makers and industry in assessing the cradle-to-grave impacts of a 
product or process. Gładysz and Ziębik (2015) performed an LCA analysis of an oxy-fuel combustion power plant with $\mathrm{CO}_{2}$ capture, transport and storage. Blanco-Marigorta et al. (2014) performed an exergo-environmental analysis, an analysis that combines an energy analysis and a life cycle assessment, of a reverse osmosis desalination plant in Gran Canaria. Stanek et al. (2015) using the LCA methodology together with thermo-ecological cost analysis performed an exergo-ecological evaluation of different types of hard coal. Chan et al. (2015) presented a life cycle assessment of a biomass hydrothermal liquefaction process for bio-oil production. The study showed that three process parameters have the most influence on the hydrothermal liquefaction process, and these are: temperature, pressure and reaction time on the subcritical and supercritical hydrothermal liquefaction. Zambrana-Vasquez et al. (2015) performed an environmental evaluation of domestic solar hot water systems, based on the LCA methodology. The aim of the study was to compare the environmental performance of solar hot water systems and to select the best environmentally friendly solution while considering their energy pay-back time. In the USA, buildings consume approximately half of energy produced and contribute closely to half of greenhouse gas emissions; consequently, Russell-Smith et al. (2015) investigated more sustainable building designs. By using the combined LCA and target value design (TVD), the study demonstrated that buildings can be designed to perform at higher environmental standards. The transport sector is also one of the major energy consumers. Bartolozzi et al. (2013) for a region in Italy compared the use of hydrogen and electric vehicles by LCA. The results of this study give some indications on the environmental aspects of using hydrogen vehicles, where hydrogen is produced from renewable energy sources, and electric vehicles as a potential alternative to fossil fuel-fed vehicles. The papers of this SI section are a worthy extension of the previous papers sponsored by SDEWES.

\section{Future energy systems}

Regarding the future energy systems topic, published papers of this SI section addressed the same complexity of sustainable energy systems issue previously focused on small isolated community (Calise et al. 2015), county (Zhang et al. 2015), municipal (Kostevšek et al. 2016), city (Martinez 2015), national (Zakeri et al. 2015), and regional level (Kettl et al. 2014).

Power production based on fossil fuels involves harmful emissions. Consequently, there have been studies that analysed the efficiency improvement and pollutant formation in existing coal-fired furnaces (Kobayashi et al. 2014). Furthermore, Mikulandrić et al. (2013) presented possibilities of implementation of advanced combustion control concepts in order to improve the existing coal-fired thermal power plants performance. However, most research on existing pulverised fuel furnaces studied the co-firing concept since the substitution of coal by alternative renewable fuels has been recognised as a $\mathrm{CO}_{2}$ mitigation option (Moiseyev et al. 2014). This concept has been studied on the laboratory scale (Wang et al. 2016a), large industrial scale (Liu et al. 2014), both experimentally and numerically by Mikulčić et al. (2014) and in the subsequent study by Mikulčić et al. (2016a) and shows that there is a great opportunity of using renewable fuels in existing pulverised fuel furnaces. Hoffmann et al. (2014) studied the co-combustion of coal and eucalyptus. Mehmood et al. (2015) studied the influence of the co-combustion of two types of coal and four types of biomass, and their corresponding influence on the pollutant formation and gas temperature.

In contrast to power production from fossil fuels, the research on the generation of power from renewable energy sources (RES) and their efficient utilisation is one of the most prominent areas of energy research. Energy generated by photovoltaics (PV) and wind power has been the topic of many studies. Quoilin and Orosz (2013) in their study showed that PV installations have a great potential also in remote rural areas, vice versa Cellura et al. (2013) analysed the effectiveness of photovoltaic systems operating in a dense urban area. The studies on wind energy generation include the estimation of the wind potential (Rotich et al. 2014) and the socio-economic benefits of wind power (Simas and Pacca 2013).

\section{Water-energy nexus and water networks}

Water-energy nexus and water networks topic has been researched extensively over the years. Water and energy resources are inseparably linked to support human welfare (Vieira et al. 2016). Water is needed to produce energy, and energy is used to clean, desalinate and transport water. To deal with anthropogenic pressure and climate change, longterm solutions to water scarcity and energy demand need to be developed jointly (Dubreuil et al. 2013). The study by Calise et al. (2014) investigated the integration of solar and geothermal energy in a novel polygeneration system that simultaneously produces electricity, thermal energy, cooling energy and fresh water. The study showed that for small isolated communities water-energy nexus is also of great economic importance, especially if the availability of solar and geothermal energy is high, whereas the availability of fresh water is scarce and its cost is consequently high. In the study by Waite and Modi (2014), the water-energy nexus was studied in terms of the potential increase of wind-generated electricity utilisation by the use of heat pumps. The 
study evaluated the coupling effects of large-scale wind power installations with increased use of electric heat pumps to meet a portion of space heating and domestic hot water demands in a major US city. The analysis showed significant increases in wind-generated electricity utilisation with increased use of heat pumps, allowing for higher installed capacity of wind power.

As the availability of fresh water and its management in water-stressed regions is becoming more and more emphasised, several studies analysed this subject (Polomčić et al. 2015). The supply of drinkable water was also studied by Novosel et al. (2014) and by a recent study by Novosel et al. (2015) The study analysed the integration of intermittent renewable energy resources and reverse osmosis desalination in Jordan. As Jordan is located in an arid region, the paper showed that the desalination plants can produce the much needed fresh water.

A novel general superstructure and a simultaneous optimisation model for the designing of a heat-integrated water-using and wastewater treatment network by combining a water-using network, a wastewater treatment network, and a heat exchanger network was presented in the study by Ahmetovic et al. (2014). The papers of this SI section that belong to this category are to be seen in this backdrop.

\section{Waste management}

Papers dealing with the waste management topic of research, over the years, included studies from the solid waste collection, recycling, management, waste-to-energy, the formation of air pollutants, and finally the socio-economic aspects of the modern waste management. Thus, Schneider et al. (2012) analysed the cost-effectiveness of greenhouse gas emission reduction measures and energy recovery from municipal waste. The study showed that a substantial amount of energy could be generated and greenhouse gas emissions avoided if measures for recovering energy from municipal solid waste would be applied in Croatia.

The hazardous waste and heavy metal contamination of soil and water are a growing environmental issue worldwide. The most common heavy metal contaminating industries are metal plating, mining operations, battery manufacturing, paints and pigments, ammunition, ceramic and glass industries. The treatment of such contaminated wastewater with waste marigold flowers was investigated by Mondal et al. (2015). The study showed that waste marigold flower is an efficient adsorbent for removal of Cadmium (II) and Chromium (VI) from aqueous solutions. As for the handling of hazardous waste from municipal solid waste incinerator plants, i.e. fly ash from the incinerator, this was studied by Hartmann et al. (2015). The study showed that special handling of such waste material is needed since it often contains heavy metals that they can harm human health.

Waste-to-energy topic has been the subject of research of several different studies ( $\mathrm{Ng}$ et al. 2014). Some of the studies investigated the production of gaseous fuel from sewage sludge and organic fraction of the municipal solid waste (Werle and Duzdiak 2015); other studies analysed the production of biofuels from food waste and waste cooking oil (Chuah et al. 2016). López-Sabirón et al. (2015) studied the syngas production from refuse-derived fuel (RDF) by a plasma torch gasification technology. The study showed that plasma torch gasification for waste-toenergy recovery in the cement industry is environmentally feasible. What is common to all of the studies dealing with the waste-to-energy topic is that they showed that if treated carefully, waste can be considered as a resource for energy production and substitute the use of fossil fuels.

\section{$\mathrm{CO}_{2}$ emission from industry and due to land use change for biofuel cultivation}

When it comes to the $\mathrm{CO}_{2}$ emissions topic, over the year this subject has been investigated by a number of papers, including those published in this SI section. There have been papers investigating various $\mathrm{CO}_{2}$ mitigation options in different industrial sectors. These include the power production sector, energy-intensive industrial sectors, such as steel and cement industry, some less energy-intensive sectors such as wood industry. Dal Magro et al. (2015) investigated the efficient energy recovery from off-gas in the steel industry. Mikulčić et al. (2013), and in later studies, Mikulčić et al. (2016b) and in the most recent study by Mikulčić et al. (2016c) investigated the potential for reducing $\mathrm{CO}_{2}$ emissions from cement industry. All of these studies showed that $\mathrm{CO}_{2}$ mitigation measures can reduce the effect industrial manufacturing has on the environment and can make it more competitive.

Power production sector is one of a major $\mathrm{CO}_{2}$-emitting sector. It has been extensively studied over the years (Kazagić et al. 2014). Carbon emissions capture and storage (CCS) technologies are seen as crucial for removing $\mathrm{CO}_{2}$ emissions from the power sector because large-scale deployment of these technologies is expected to reduce wholesale electricity prices and decarbonisation cost significantly (Hanak et al. 2016). The studies analysing the effect of retrofitting existing fossil fuel power plants with CCS showed that CCS requires a large capital investment and significantly increases the levelised cost of electricity. However, the economic viability of CCS increases with higher $\mathrm{CO}_{2}$ prices (Liew et al. 2014). 


\section{Mathematical modelling and numerical simulations}

Mathematical modelling and numerical simulation topic has been studied by a number of papers published in the SDEWES special issues in the recent past. Numeric techniques are increasingly used to develop more efficient equipment, resulting in less fuel consumption and optimal chemical reactions in industrial equipment. Over the years, there were studies devoted to the application of methods and software tools of computational fluid dynamics (CFD) to the modelling of pollutant formation, and the heat and mass transfer.

Wang et al. (2016b) analysed the influence of the particle dispersion onto the continuous phase in film cooling application. The study showed that interaction between the water droplets and the mainstream plays an important role in the cooling performance, and further that mist injection can significantly enhance the film cooling performance. Milani et al. (2014) numerically analysed the combustor for a co-generation system based on the aluminium/water reaction. The study showed that numerical approach is beneficial when evaluating the design of the combustion chamber and the interaction between the liquid aluminium jet and the water steam flow. Ma et al. (2015) studied the local thermal-hydraulic performance and optimisation of zigzag-type printed circuit heat exchanger at high temperature. The study showed that heat transfer enhancement method with inclined angles completely depends on the operating conditions. Hamid et al. (2014) studied the fluid flow and convective heat transfer inside a pre-heater of a desalination unit. The study showed that by using the numerical simulations, the optimisation of the pre-heater and increase in the heat transfer rate can be achieved. Rieger et al. (2015) investigated the formation of nitrogen oxide (NO) for the combustion of enriched blast furnace gas inside a blast stove. The study showed that numerical results can be used by plant operators to control for temperature level and gas feed ensuring the compliance with legal pollution limits. Baleta et al. (2015) and in the subsequent study Baleta et al. (2016), using the CFD simulations, studied the use of urea water solution for $\mathrm{NO}_{\mathrm{x}}$ mitigation by both selective catalytic reduction and the selective non-catalytic reduction process. Both studies showed that CFD simulations can be used for improving the efficiency of the deNO ${ }_{x}$ process. Mikulčić et al. (2012) have been using the same approach to study the calcination process inside an experimental pipe reactor. The internal combustion engines and corresponding thermo-chemical processes were the topics of research of several different studies. The biogas fuelled homogeneous charge compression ignition (HCCI) engine, and the possibility of reducing the high intake temperature requirement necessary for igniting biogas in an HCCI engine was studied by Kozarac et al. (2014). The spark ignition engine was studied by Wang et al. (2015), and the diesel engine was studied by Petranović et al. (2015). The spray and combustion processes in diesel engine were analysed by Vujanović et al. (2015), and in the following study by Vujanović et al. (2016). All of these studies showed that CFD as a research tool has a broad range of application possibilities.

\section{Social and economic studies}

As for the papers investigating the social and economic research topic, most of the papers published in previous SDEWES special issues analysed the impact of different technologies, processes and management options on the human welfare (Novak Pintarič et al. 2015). Thus, the socio-economic aspects of the switch from non-renewable energy resources to renewable energy resources were analysed by Kozioł and Mendecka (2015). The social inclusion and socio-economic aspects of the electrification of isolated communities were investigated by Gómez et al. (2013) and by Quoilin and Orosz (2013). Public acceptance of future energy systems and energy infrastructure was investigated by Hake et al. (2015). Klemeš et al. (2013) discussed the challenges of modern engineering education in the field of energy systems. The study showed that new engineering curricula should educate energy engineers to manage and solve their problems in a sustainable way. The socio-economic aspects of district heating systems were analysed in a study by Petrovic and Karlsson (2014). As for the socio-economic performance of different technologies, this topic was the subject of several studies. Zhang et al. (2014) performed a socio-economic study of a novel solar photovoltaic/loop-heat-pipe heat pump water heating system for application in three different climatic regions. Heyne and Harvey (2013) performed an energy and economic assessment of the second generation biofuel production processes using energy market scenarios. Autotrophic production of biodiesel from microalgae and its economic assessment was investigated by Tercero et al. (2014). Kostowski et al. (2014) performed a thermo-economic analysis of a plant using natural gas for power production. Studies by Rokni (2014) presented a thermoeconomic analysis of an integrated biogas-fuelled solid oxide fuel cell (SOFC) system for electric power generation. Nemet et al. (2013) performed an economic performance analysis for a heat exchanger network. Finally, when it comes to the interaction between income growth and freshwater use, this has been studied by Katz (2015). 
In conclusion, these are just some of the papers from previous SDEWES conferences that have contributed to the knowledge increase within these seven research topics. Further research within all of these topics is needed.

\section{Research themes and areas represented in this special issue section}

Two papers dealing with the life cycle assessment (LCA) theme present a life cycle assessment for a bio-oil production and for carbon emissions capture and storage (CCS). The first paper focused on two alternative processes for the production of bio-oil from Malaysian oil palm empty fruit bunch evaluated and compared them in terms of their impacts on the environment, specifically based on the selected impact categories: global warming potential, acidification, eutrophication, toxicity and photochemical oxidant formation. The second paper using the LCA approach analysed different concepts of CCS technologies for coal-fired power plants. Based on those studies, several different approaches for CCS can be compared directly.

Papers dealing with future energy systems studied the possibilities and sustainability of reliable and secure supplies of energy. Since the environmental impacts of fossil fuels use have become hard to ignore, use of renewable energy resources is more and more promoted worldwide.

The water-energy nexus and water networks issue, dealt by two papers, investigated the secure, safe and efficient water and energy supply. This issue is of significant importance to remote communities, such as islands and isolated settlements in arid areas that rely on energy-intensive water supply systems, which are inherently costly to operate.

There are two papers that deal with the waste management theme. The first paper estimated disaster waste that can be potentially generated by a natural disaster, in order for the waste management system to respond adequately to such events. Application of waste ceramic dust as a readyto-use replacement of cement in lime-cement plasters was analysed in the second paper. The study reported that the use of waste ceramic dust in plasters is an environmentalfriendly and energy-efficient solution for waste ceramic dust utilisation.

Reduction of greenhouse gas emissions, especially the $\mathrm{CO}_{2}$ emissions, over the years due to environmental concerns has attracted worldwide attention. As $\mathrm{CO}_{2}$ emissions are closely linked to energy generation, industry, transportation and agriculture cultivation, various studies investigated the reduction of fossil fuel use, land use change and as well the $\mathrm{CO}_{2}$ emissions reduction potential. The three papers dealing with this issue contribute to the increase of knowledge in this field of research.
Over the years, mathematical modelling and numerical simulations have become an integral component of research in various research areas. The two papers analysed two different systems. The first paper by the use of mathematical modelling investigated the desalination systems. The second paper using the computational fluid dynamics (CFD) analysed the air staging inside a coke oven heating system, as a primary method of nitrogen oxide (NO) formation reduction. The study demonstrated the positive effect of the considered air staging on $\mathrm{NO}$ formation reduction.

The social and economic aspect is very important in the sustainability assessment of different systems. In recent years, it is becoming more and more evident that so-called green initiatives, which ignore social and economic aspects, are doomed to failure. The fourth paper dealing with the social and economic issues, within this SI section, build upon the previously generated knowledge and present a new approach for dealing with such important issues.

\section{Conclusions}

This overview addresses the recent research works on seven topics of sustainable development named as: life cycle assessment; future energy systems; water-energy nexus and water networks; waste management; $\mathrm{CO}_{2}$ emission from industry and due to land use change for biofuel cultivation; mathematical modelling and numerical simulations; social and economic studies. Despite the important developments in all of the areas considered, there are still some great challenges to be addressed, especially when it comes to social and human welfare. The main intended message of this paper is that the sustainability can be improved by integrating various systems in a way to improve the overall efficiency of the combined system.

\section{References}

Ahmetović E, Ibrić N, Kravanja Z (2014) Optimal design for heatintegrated water-using and wastewater treatment networks. Appl Energy 135:791-808

Baleta J, Vujanović M, Pachler K, Duić N (2015) Numerical modeling of urea water based selective catalytic reduction for mitigation of NOx from Transport Sector. J Clean Prod $88: 280-288$

Baleta J, Mikulčić H, Vujanović M, Petranović Z, Duić N (2016) Numerical simulation of urea based selective non-catalytic reduction deNOx process for industrial applications. J Energy Convers Manag. doi:10.1016/j.enconman.2016.01.062

Bartolozzi I, Rizzi F, Frey M (2013) Comparison between hydrogen and electric vehicles by life cycle assessment: a case study in Tuscany, Italy. Appl Energy 101:103-111 
Blanco-Marigorta AM, Masi M, Manfrida G (2014) Exergo-environmental analysis of a reverse osmosis desalination plant in Gran Canaria. Energy 76:223-232

Calise F, Cipollina A, Dentice d'Accadia M, Piacentino A (2014) A novel renewable polygeneration system for a small Mediterranean volcanic island for the combined production of energy and water: dynamic simulation and economic assessment. Appl Energy 135:675-693

Calise F, Dentice d'Accadia M, Piacentino A (2015) Exergetic and exergoeconomic analysis of a renewable polygeneration system and viability study for small isolated communities. Energy 92:290-307

Cellura M, Di Gangi A, Orioli A (2013) Assessment of energy and economic effectiveness of photovoltaic systems operating in a dense urban context. J Sustain Dev Energy Water Environ Syst 1:109-121

Chan YH, Yusup S, Quitain AT, Tan RR, Sasaki M, Lam HL, Uemura Y (2015) Effect of process parameters on hydrothermal liquefaction of oil palm biomass for bio-oil production and its life cycle assessment. Energy Convers Manag 104:180-188

Chuah LF, Klemeš JJ, Yusuo S, Bokhari A, Akbar MM, Chong ZK (2016) Kinetic studies on waste cooking oil into biodiesel via hydrodynamic cavitation. J Clean Prod. doi:10.1016/j.jclepro. 2016.06.187

Dal Magro F, Meneghetti A, Nardin G, Savino S (2015) Enhancing energy recovery in the steel industry: matching continuous charge with off-gas variability smoothing. Energy Convers Manag 104:78-89

Dubreuil A, Assoumou E, Bouckaert S, Selosse S, Mari N (2013) Water modeling in an energy optimization framework-the water-scarce Middle East context. Appl Energy 101:268-279

Gładysz P, Ziębik A (2015) Life cycle assessment of an integrated oxy-fuel combustion power plant with $\mathrm{CO}_{2}$ capture, transport and storage-Poland case study. Energy 92:328-340

Gómez FM, Sanches-Pereira A, Silveira S (2013) Technology for social inclusion: the case of electricity access in the Brazilian Amazon. J Sustain Dev Energy Water Environ Syst 1:237-259

Hake J-F, Fischer W, Venghaus S, Weckenbrock C (2015) The German energiewende -history and status quo. Energy 92:532-546

Hamid MOA, Zhang B, Yang L (2014) Application of field synergy principle for optimization fluid flow and convective heat transfer in a tube bundle of a pre-heater. Energy 76:241-253

Hanak DP, Kolios AJ, Manovic V (2016) Comparison of probabilistic performance of calcium looping and chemical solvent scrubbing retrofits for $\mathrm{CO}_{2}$ capture from coal-fired power plant. Appl Energy 172:323-336

Hartmann S, Koval L, Škrobánková H, Matýsek D, Winter F, Purgar A (2015) Possibilities of municipal solid waste incinerator fly ash utilization. Waste Manag Res 33:740-747

Heyne S, Harvey S (2013) Assessment of the energy and economic performance of second generation biofuel production processes using energy market scenarios. Appl Energy 101:203-212

Hoffmann BS, Szklo A, Schaeffer R (2014) Limits to co-combustion of coal and eucalyptus due to water availability in the state of Rio Grande do Sul, Brazil. Energy Convers Manag 87:1239-1247

Katz D (2015) Water use and economic growth: reconsidering the environmental Kuznets curve relationship. J Clean Prod 88:205-213

Kazagić A, Merzić A, Redžić E, Musić M (2014) Power utility generation portfolio optimization as function of specific RES and decarbonisation targets-EPBiH case study. Appl Energy 135:694-703

Kettl K-H, Niemetz N, Eder M, Narodoslawsky M (2014) Optimal renewable energy systems for regions. J Sustain Dev Energy Water Environ Syst 2:88-99
Klemeš JJ, Kravanja Z, Varbanov PS, Lam HL (2013) Advanced multimedia engineering education in energy, process integration and optimization. Appl Energy 101:33-40

Kobayashi M, Nakao Y, Oki Y (2014) Exhaust circulation into dry gas desulfurization process to prevent carbon deposition in an Oxy-fuel IGCC power generation. Energy Convers Manag 87:1315-1323

Kostevšek A, Petek J, Klemeš JJ, Varbanov P (2016) Municipal energy policy constitution and integration process to establish sustainable energy systems - a case of the Slovenian municipality. J Clean Prod 120:31-42

Kostowski WJ, Usón S, Stanek W, Bargiel P (2014) Thermoecological cost of electricity production in the natural gas pressure reduction process. Energy 76:10-18

Kozarac D, Vuilleumiera D, Saxena S, Dibble RW (2014) Analysis of benefits of using internal exhaust gas recirculation in biogasfueled HCCI engines. Appl Energy 87:1186-1194

Kozioł J, Mendecka B (2015) Evaluation of economic, energyenvironmental and sociological effects of substituting nonrenewable energy with renewable energy sources. J Sustain Dev Energy Water Environ Syst 3:333-343

Liew PY, Klemeš JJ, Doukelis A, Zhang N, Seferlis P (2014) Identification of process integration options for $\mathrm{CO}_{2}$ capture in Greek Lignite-Fired power plant. Chem Eng Trans 39:1447-1452

Liu Y, Wang X, Xiong Y, Tan H, Niu Y (2014) Study of briquetted biomass co-firing mode in power plants. Appl Therm Eng 63:266-271

López-Sabirón AM, Fleiger K, Schäfer S, Antoñanzas J, Irazustabarrena A, Aranda-Usón A, Ferreira GA (2015) Refuse derived fuel (RDF) plasma torch gasification as a feasible route to produce low environmental impact syngas for the cement industry. Waste Manag Res 33:715-722

Ma T, Li L, Xu X-Y, Chen Y-T, Wang Q-W (2015) Study on local thermal-hydraulic performance and optimization of zigzag-type printed circuit heat exchanger at high temperature. Energy Convers Manag 104:55-66

Martinez CIP (2015) Energy and sustainable development in cities: a case study of Bogotá. Energy 92:612-621

Mehmood S, Reddy BV, Rosen MA (2015) Emissions and furnace gas temperature for electricity generation via co-firing of coal and biomass. J Sustain Dev Energy Water Environ Syst 3:344-358

Mikulandrić R, Lončar D, Cvetinović D, Spiridon G (2013) Improvement of existing coal fired thermal power plants performance by control systems modifications. Energy 57:55-65

Mikulčić H, von Berg E, Vujanović M, Priesching P, Perković L, Tatschl R, Duić N (2012) Numerical modelling of calcination reaction mechanism for cement production. Chem Eng Sci 69:607-615

Mikulčić H, Vujanović M, Duić N (2013) Reducing the $\mathrm{CO}_{2}$ emissions in Croatian cement industry. Appl Energy 101:41-48

Mikulčić H, von Berg E, Vujanović M, Duić N (2014) Numerical study of co-firing pulverized coal and biomass inside a cement calciner. Waste Manag Res 32:661-669

Mikulčić H, von Berg E, Vujanović M, Wang X, Tan H, Duić N (2016a) Numerical evaluation of different pulverized coal and solid recovered fuel co-firing modes inside a large-scale cement calciner. Appl Energy. doi:10.1016/j.apenergy.2016.05.012

Mikulčić H, Cabezas H, Vujanović M, Duić N (2016b) Environmental assessment of different cement manufacturing processes based on emergy and ecological footprint analysis. J Clean Prod 130:213-221

Mikulčić H, Klemeš JJ, Vujanović M, Urbaniec K, Duić N (2016c) Reducing greenhouse gasses emissions by fostering the deployment of alternative raw materials and energy sources in the 
cleaner cement manufacturing process. J Clean Prod. doi:10. 1016/j.jclepro.2016.04.145

Milani M, Montorsi L, Paltrinieri F, Stefani M (2014) Experimental and numerical analysis of the combustor for a cogeneration system based on the aluminum/water reaction. Energy Convers Manag 87:1291-1296

Moiseyev A, Solberg B, Kallio AMI (2014) The impact of subsidies and carbon pricing on the wood biomass use for energy in the EU. Energy 76:161-167

Mondal MK, Mishra G, Kumar P (2015) Adsorption of Cadmium (II) and Chromium (VI) from aqueous solution by waste marigold flowers. J Sustain Dev Energy Water Environ Syst 3:405-415

Nemet A, Klemeš JJ, Kravanja Z (2013) Optimising entire lifetime economy of heat exchanger networks. Energy 57:222-235

Ng WPQ, Lam HL, Varbanov PS, Klemeš JJ (2014) Waste-to-Energy (WTE) network synthesis for Municipal solid waste (MSW). Energy Convers Manag 85:866-874

Novak Pintarič Z, Varbanov PS, Klemeš JJ, Kravanja Z (2015) Evaluating the economic efficiency of the technologies for greenhouse gas footprint reduction. Chem Eng Trans 45:535-540

Novosel T, Ćosić B, Krajačić G, Duić N, Pukšec T, Mohsen MS, Ashhab MS, Ababneh AK (2014) The influence of reverse osmosis desalination in a combination with pump storage on the penetration of wind and PV energy: a case study for Jordan. Energy 76:73-81

Novosel T, Ćosić B, Pukšec T, Krajačić G, Duić N, Mathiesen BV, Lund H, Mustafa M (2015) Integration of renewables and reverse osmosis desalination-case study for the Jordanian energy system with a high share of wind and photovoltaics. Energy 92:270-278

Petranović Z, Vujanović M, Duić N (2015) Towards a more sustainable transport sector by numerically simulating fuel spray and pollutant formation in diesel engines. $\mathrm{J}$ Clean Prod 88:272-279

Petrovic SN, Karlsson KB (2014) Danish heat atlas as a support tool for energy system models. Energy Convers Manag 87:1063-1076

Polomčić D, Bajić D, Zarić J (2015) Determining the groundwater balance and radius of influence using hydrodynamic modeling: case study of the groundwater source "Šumice" in Serbia. J Sustain Dev Energy Water Environ Syst 3:217-229

Quoilin S, Orosz M (2013) Rural electrification through decentralized concentrating solar power: technological and socio-economic aspects. J Sustain Dev Energy Water Environ Syst 1:199-212

Rieger J, Weiss C, Rummer B (2015) Modelling and control of pollutant formation in blast stoves. J Clean Prod 88:254-261

Rokni M (2014) Thermodynamic and thermoeconomic analysis of a system with biomass gasification, solid oxide fuel cell (SOFC) and stirling engine. Energy 76:19-31

Rotich NK, Backman J, Linnanen L, Daniil P (2014) Wind resource assessment and forecast planning with neural networks. J Sustain Dev Energy Water Environ Syst 2:174-190

Russell-Smith SV, Lepech MD, Fruchter R, Meyer YB (2015) Sustainable target value design: integrating life cycle assessment and target value design to improve building energy and environmental performance. J Clean Prod 88:43-51
Schneider DR, Kirac M, Hublin A (2012) Cost-effectiveness of GHG emission reduction measures and energy recovery from municipal waste in Croatia . Energy 48:203-211

Simas M, Pacca S (2013) Socio-economic Benefits of Wind Power in Brazil. J Sustain Dev Energy Water Environ Syst 1:27-40

Stanek W, Czarnowska L, Pikon K, Bogacka M (2015) Thermoecological cost of hard coal with inclusion of the whole life cycle chain. Energy 92:341-348

Tercero EAR, Domenicali G, Bertucco A (2014) Autotrophic production of biodiesel from microalgae: an updated process and economic analysis. Energy 76:807-815

Vieira AS, Humphrys S, Beal CD, Stewart RA (2016) Optimising residential water heating system performance to minimise waterenergy penalties. J Sustain Dev Energy Water Environ Syst 4:161-172

Vujanović M, Petranović Z, Edelbauer W, Baleta J, Duić N (2015) Numerical modelling of diesel spray using the Eulerian multiphase approach. Energy Convers Manag 104:160-169

Vujanović M, Petranović Z, Edelbauer W, Duić N (2016) Modelling spray and combustion processes in diesel engine by using the coupled Eulerian-Eulerian and Eulerian-Lagrangian method. J Energy Convers Manag. doi:10.1016/j.enconman.2016.03.072

Waite M, Modi V (2014) Potential for increased wind-generated electricity utilization using heat pumps in urban areas. Appl Energy 135:634-642

Wang T, Zhang X, Xu J, Zheng S, Hou X (2015) Large-eddy simulation of flame-turbulence interaction in a spark ignition engine fueled with methane/hydrogen/carbon dioxide. Energy Convers Manag 104:147-159

Wang X, Deng S, Tan H, Adeosun A, Vujanović M, Yang F, Duić N (2016a) Synergetic effect of sewage sludge and biomass copyrolysis: a combined study in thermogravimetric analyzer and a fixed bed reactor. Energy Convers Manag 118:399-405

Wang J, Cui P, Vujanović M, Baleta J, Duić N, Guzović Z (2016b) Effects of surface deposition and droplet injection on film cooling. Energy Convers Manag. doi:10.1016/j.enconman.2016. 03.038

Werle S, Duzdiak M (2015) The assessment of sewage sludge gasification by-products toxicity by ecotoxicologial test. Waste Manag Res 33:696-703

Zakeri B, Syri S, Rinne S (2015) Higher renewable energy integration into the existing energy system of Finland-is there any maximum limit? Energy 92:244-259

Zambrana-Vasquez D, Aranda-Usón A, Zabalza-Bribián I, Jañez A, Llera-Sastresa E, Hernandez P, Arrizabalaga E (2015) Environmental assessment of domestic solar hot water systems: a case study in residential and hotel buildings. J Clean Prod 88:29-42

Zhang X, Shen J, Xu P, Zhao X, Xu Y (2014) Socio-economic performance of a novel solar photovoltaic/loop-heat-pipe heat pump water heating system in three different climatic regions. Appl Energy 135:20-34

Zhang H, Baeyens J, Degreve J (2015) The Potential of a hybrid power plant for the Dubrovnik-Neretva County. J Sustain Dev Energy Water Environ Syst 3:174-182 